\title{
THE PROSPECT OF RADAR REMOTE SENSING IN ASSESSMENT OF FOREST ABOVE GROUND BIOMASS
}

\author{
YOGESH KUMAR
}

Scholar, Technical Officer, MoEF\& CC, New Delhi

\begin{abstract}
The assessment of forest Above Ground Biomass (AGB) is a major requirement in the current scenario where world faces a serious threat of climate change. The assessments of AGB or carbon stock are carried out in various ways. The allometric equations were developed which were used for the estimation of plot level stand volume. The Land Use Land Cover (LULC) observations and signal measurements by satellite have now-a-days become an important tool in estimation of $A G B$ in forests. The remote sensing techniques were widely used in the assessment of biomass across globe, by establishing relationship between field level biomass and spectral responses/vegetation indices derived from multispectral images. However, frequent cloud coverage hinders the acquisition of all weather data in the optical sensors. The Radar Remote Sensing has an advantage of its own illumination (signal) hand hence independent of sun illumination. The active nature of radar remote sensing makes it applicable to work during day and night, penetrate clouds, canopy, snow, rain, etc. The Synthetic Aperture Radar (SAR) sensors are transmitting microwave energy from $3 \mathrm{~cm}$ (X-band) to $100 \mathrm{~cm}$ (P-band). The space borne SAR seems to be very useful for measuring biomass and forest carbon tracking over a large area. The longer wavelength and shorter featuring SAR data is capable to penetrate deep inside the forest and its weak backscatter coefficient from rough surface makes it crucial for the estimation of forest AGB. This review tells about the capabilities of radar remote sensing in the assessment of biomass along with the most adopted methodologies. It deals primarily the application of polarimetric SAR in forest above ground biomass mapping.
\end{abstract}

KEYWORDS: Biomass, Allometric equations, Synthetic Aperture Radar (SAR) \& Backscatter

Received: Apr 05, 2020; Accepted: Apr 25, 2020; Published: May 20, 2020; Paper Id.: IJASRJUN202004

\section{INTRODUCTION}

The National Forest Policy of 1988 paved the way for sustainable management of forests through conservation. It has framed guidelines to increase the forest and tree cover inside the forest and outside forest land through large scale afforestation and social forestry programmes on the available denuded, degraded and unproductive land. It has been reported that the policies and the programs has helped to achieve an increase in total forest carbon stocks amounting to $10.01 \mathrm{GtC}$ over a period of 20 years (1986-2005) (FAO 2005). The study has further suggested that there will be an increase and accumulation of 8.79 to 9.75 GtCcarbon in the forests during the period 2006-30 (IISc 2006) and the ongoing implementation of afforestation and reforestation programme leads to a new forest carbon additions (Ravindranath et al. 2008). As per ISFR 2019 report, the total carbon stock in the country's forest is assessed to be 7,124 million tones. An increase of 42.6 million tonnes has been observed as compared to last assessment. The increase in the carbon stock is in line with the Intended Nationally Determined Contributions (INDC) targets. The INDC target for forestry sector envisions for building an additional carbon sink of 2.5 to 3.0 billion tonnes of $\mathrm{CO}_{2}$. The accurate estimation and reporting of Above Ground Biomass (AGB) and carbon of forest is an immediate requirement of international conventions (e.g. the Unites Nations Framework Convention on Climate Change (UNFCCC), Reducing Emissions from Deforestation and forest Degradation (REDD, REDD+) 
which considers mitigation and conservation plans followed by sustainable forest management, integrated policy development and its implementation, precise greenhouse gases flux estimation and carbon stock enrichment (Gibbs et al. 2007, UNFCCC, 2011).

\section{Conventional Method}

During past, destructive methods were adopted which were also known as the harvest method. According to Gibbs et al. 2007, at that time, those methods were the most practical and convenient method for the estimation of forest AGB and the carbon stocks accumulated in the forest ecosystem. The trees were harvested in the sample plot and weighted along with their components like tree stem, branches and leaves in the field. The collected materials were oven dried and weighted again for estimation of moisture content. Further, due to loss of species it has been suggested to develop location and species-specific allometric equations which will be used for estimation of biomass and carbon on a large scale without harming the plants. The species specific allometric equations were based on the assumptions that every biophysical part of trees reflects their alliance with each other. During the exercise of forest inventory, different biophysical parameters of trees like diameter at breast height $(1.37 \mathrm{~m})$, Circumference at Breast Height $(\mathrm{CBH})$, height, etc. have been measured and recorded. The volumetric equations were developed using regression analysis between different biophysical parameters with AGB. Depending upon the use of various parameters in derivation of allometric equations, the volume table has been categorized under regional volume tables and local volume tables.

Various scientists and research scholars have estimated forest biomass and carbon stock under different time period across different physiographical zones of India (Ravindranath et al. 1997, Lal and Singh, 2000, Chhabra et al. 2002) taking the Growing Stock (GS) into their account. Later volume equations were chosen as the primary source of equations for volume estimation. The specific gravity has been taken into account for the estimation of tree biomass (tree volume $*$ specific gravity). The tree biomass has been converted into carbon by multiplying it by a factor of 0.47 (IPCC 2006). Later on, Forest Survey of India has published its book containing volume equations for various species in various regions of India after ding exhaustive field inventory. In present scenario, various scientists have worked independently for the estimation of species specific volumetric equations in specific physiographic zone. Kale et al. 2004 has developed in Madhya Pradesh, Mani and Parthasarathy 2007 in tropical dry evergreen forest of peninsular India.Singh et al. 2011, derive regression based allometric equations for tree species having a diameter at breast height $<10 \mathrm{~cm}$.

\section{Remote Sensing Approach}

The technique of remote sensing for the estimation of biomass and carbon over the large area depends upon the correlation between the spectral reflectance from the canopy at the sensor and in-situ field inventory (Chiesi et al. 2005, Myeong et al. 2006, Gibbs et al. 2007, Tan et al. 2007, Bastin et al. 2014). The earlier studies had correlated the spectrally derived vegetation index directly to vegetation volume (above ground biomass) and primary productivity (Tucker et al. 1983, Goward and Dave, 1987, Huete et al. 2002, Nakaji et al. 2008).The Forest survey of India in 1995 had carried out the first ever woody stock assessment in Indian forests using the field inventory data (1965-1990), thematic maps and forest cover data. On subsequent development of technology, remote sensing technique has been used extensively for mapping of crown densities and forest area which was further integrated with field inventory data for the estimation of biomass and carbon. It was estimated and reported that the Indian forests holds an amount of 4,017 $\mathrm{Tg}$ Carbon and its density has reported to be $63.6 \mathrm{Mg} \mathrm{C/ha} \mathrm{(Dadhwal \&} \mathrm{Shah} \mathrm{1997).} \mathrm{In} \mathrm{another} \mathrm{study} \mathrm{carried} \mathrm{out} \mathrm{by} \mathrm{Chhabraet} \mathrm{al.2002,} \mathrm{it} \mathrm{has} \mathrm{reported}$ that the Indian forests hold carbon in a range between 3871.2 to $3874.3 \mathrm{Tg} \mathrm{C}$. The technique of remote sensing data and 
GIS has beenfurther advanced with the launch of various satellites which were capable to monitor vegetation in the respective spectral region for mapping forest biomass and carbon stocks (Ramachandran et al. 2007, Kale et al. 2009, Bijalwan et al. 2010, Pandey et al. 2010. It has been reported that the spectral signature and its reflectance from the objects are affected by the degree of aspects and slopes (Bijalwan et al. 2010).Till then, the assessment were very limited to local forests, but there was a huge difference in the values of forest carbon being reported by scientists and organizations. Thus, it has been felt to create a forest carbon data bank for all the forest types across the country using the integration of satellite derived data and forest inventory data which will help in achieving sustainable managed of forests (Ramachandran et al. 2007,). One of the non-parametric method adopted to achieve the objective was the use of regression technique between satellite based derivatives such as NDVI and other vegetation indices, Leaf Area Index (LAI), Digital Elevation Model (DEM) etc and field measured biomass (Madugundu et al. 2008; Kale et al. 2009; Sharma et al. 2010; Thakur and Swamy 2010; Kumar et al. 2011; ISFR 2011; Sheikh et al. 2011). With the advancement of technology and the concern of global climate change, it becomes necessary to quantify the amount of biomass and carbon in the forests. The accurate estimation of biomass becomes an essential tool for sustainable management of forest and mitigation of climate change. As per published ISFR, it been observed that there is a continuous increase in forest cover as well as forest biomass which is a reflection of government policies and programs. The use of satellite data has seen a continuous reform with the advent of technology. Earlier, the coarse resolution satellite such as MODIS, AVHRR etc having spatial resolution of 100m and above was used for the forestry applications. It was further evolved with moderate resolution (Landsat, LISS III, Sentinal etc.) images having spatial resolution upto $30 \mathrm{~m}$, high resolution (LISS IV) satellite upto resolution of $5 \mathrm{~m}$ and very high resolution (GeoEye, Worldview etc) having resolution of $1 \mathrm{~m}$ and less. The evolution of technology has advanced the application of satellite remote sensing in the field of forestry. The higher spatial resolution distinguishes between closely placed object which helps in mapping of most isolated patches of forest and its management (Lu et al. 2016, Wang et al. 2009). Apart from many studies, it has not been able to map and estimate the accurate amount of biomass and carbon of forest. It has been mentioned that the optical satellite are less sensitive to higher range of biomass in the forest. The optical data saturates at low biomass level which makes it difficult to map and model high biomass region. The tropical and subtropical forest holds higher amount of biomass in itself, thus optical remote sensing becomes limitation for estimation of forestry parameters. It has also been mentioned that the acquisition of image from optical remote sensors becomes difficult during disturbed atmospheric conditions such as rain, cloud, hailstorm, cyclones etc (Nichol and Sarker, 2011). In hilly terrain, various topographic factors such as slope, aspect affect the strength of relationship between vegetation and spectral reflectance. The optical data has limitations in spatial, spectral and radiometric resolutions which results in mixing of physical features in single pixel. To overcome the above mentioned limitations, Radar Remote Sensing brings into the picture. To overcome these limitations, higher frequency sensor has been designed as placed in the orbit.

\section{Radar Remote Sensing for Forest above Ground Biomass Estimation}

The limitations of optical remote sensing for resource management has been tried to overcome with the wide range of Microwave remote sensing. The first mission carrying Synthetic Aperture Radar (SAR) was launched in early 1990s. The pioneer SAR satellites were European Remote Sensing satellite, Japanese Earth Resource Satellite and Radar satellite imbedded with the sensor which has unitary band in single polarization. The subsequent development in the technology had improved the characteristics of the satellite with higher spatial and temporal resolutions, different combination of polarizations such as $\mathrm{HH}, \mathrm{HV}, \mathrm{VV} \& \mathrm{VH}$, along with different acquisition modes. Recently, the large scale launch of SAR satellites has significantly improved the temporal resolution along with simultaneously acquisition of data from multiple 
spacecrafts (Cosmo Sky-Med, TerraSAR/TanDEM-X, ALOS PALSAR, Sentineletc. missions). Previously, it was a limitation, but after subsequent developments it has become easier to access and process the SAR data on a large scale which can be used by scientists, policy makers and researchers for applications in management of resources. Numerous studies has witnessed that there is a significantly positive relationship between the backscatter coefficients derived from various sensors and forest above ground biomass (Baker et al. 1994, Le Toan et al. 1992, Dobson et al. 1992, Imhoff, 1995).

A study was performed to analyze the sensitivity of the two different SAR satellites i.e. ERS-1 carrying C-band wavelength in HH polarization and JERS-1 carrying L-band wavelength in VV polarization with the forest biophysical properties (Harrell et al. 1995). To attain a greater sensitivity with the backscatter, soil moisture condition should be minimized. It has been reported that the soil moisture condition plays an important role in strength of backscatter coefficients from canopies of boreal forests using C-band sensor (Pulliainen et al. 1994, 1997, Wang et al. 1994). Due to shorter wavelength of ERS-1 C-band, it becomes more sensitive to surface moisture condition than JERS-1. The shorter wavelength such as C-band makes it very challenging to distinguish between vegetation and dry soil. The estimation of forest biomass has been tried with $\mathrm{C}$ band dual polarization (HH \& HV) RADARSAT-2 data in sub-tropical forests using non-parametric step wise multiple regression analysis for model development taking polarization ratio, texture parameters of both polarization separately (Sarkar et al. 2014). The result has reported that the models developed through backscatter coefficient of HH \& HV polarization, and their polarization ratio were inefficacious whereas combined texture parameter derived model was found to be significant for forest biomass mapping and estimation. A significant coefficient of correlation (0.78) had obtained along with a higher saturation level (532 t/ha) with least RMSE error (26.95 t/ha). This has reflected the potential of SAR data over optical data for the estimation of biomass. The Indian satellite RISAT-1 (C band) was appraised for the capacities and potential for of forests biomass estimation and mapping using Support Vector Machine (SVM) algorithm and multi linear regression model in the foothills of western Himalayas in India (Padalia and Yadav 2016). Various processing and complexities leads to a conclusion that the incidence angle is being influenced by the surface. The scattering strength depends uponthe scattering type (odd, double and diffuse) and target properties. It has further concluded that the incidence angle $\left(<35^{\circ}\right)$ was suitable for obtaining maximum diffuse (or volume) scattering in the forest.

The longer wavelength of L-Band (JERS 1, ALOS PALSAR $1 \&$ 2) makes it capable to penetrate deep inside the forest canopy which helps to retrieve physiographic components (e.g. Stem diameter, volume of tree stem, above ground dry biomass) of the forest which helps to estimate forest biomass with greater accuracy. Although the L-band backscatter intensity is being affected by the slope and topography of the terrain (Rauste 1990, Van Zyl 1993, Luckman 1998). It has already been proved that L-band has greater sensitivity and saturates usually in the range of $100-150 \mathrm{Mg} \mathrm{ha}^{-1}$ (Dobson et al. 1992, Kasischke et al. 1997, Luckman et al. 1998, Hoekman \& Quinones, 2000, Luckman et al. 2000, Saatchi et al. 2007, Mitchard et al. 2011; Santoro et al. 2006, Santoro et al. 2009, Lucas et al. 2010, Morel et al. 2011, Whittle et al. 2012, Atwood et al. 2014)). To further improve the assessment the L-Band, data has been integrated with optical data in order to improve the estimation of forest biomass with greater accuracy (Mitchard et al. 2012, Sandberg et al. 2011, Ploton et al. 2013). Many studies have been carried out for the estimation of forest above ground biomass in different forests ranging from boreal to tropical forests using SAR sensors (Harrell et al. 1995, Imhoff 1995, Kasischke et al. 1995, Lucas et al. 2010, Pulliainen et al. 1999, Santoro et al. 2006). The L-band backscatter intensity derived from slope corrected ALOS PALSAR was used to understand the relationship between backscatter coefficients and stand characteristics of 
Cryptomeria japonica and Chaemaecyparis obtuse trees in the forests of Japan (Lizuka and Tateishi 2014). It was observed that the backscatter intensity increases with an increase in biophysical parameters (DBH, Height, stem volume) for Chaemaecyparis obtuse, but it decreases with Cryptomeria japonica. The high moisture content in the heartwood of Cryptomeria japonica is responsible for such behavior in backscatter. The capabilities of L-band backscatter has also been tested in the Mangrove forests for the estimation of AGB using HH \& HV polarizations (Hamdan et al. 2014). As stated earlier, the microwave data saturates at higher biomass level and the same has been confirmed that SAR data estimated biomass up to $100 \mathrm{Mg} \mathrm{ha}^{-1}$ with greater accuracy but with the increase in plot level biomass SAR data shows its incapability.

Till now, the same polarization and its capabilities were discussed, but the later research has concluded that the cross polarized wave ( $\mathrm{HV} \& \mathrm{VH}$ ) shows greater sensitive than single polarized wave for extraction of tree parameters due to its mechanism (Luckman et al. 1997, Cartus et al. 2012). This has also been testified by Behera et al. 2015 where the cross polarized HV backscatter shows greater degree of significance as compared with co-polarized HH backscatter in Sal and teak forests. The variability in the relationship was also due to differences in vegetation structure (e.g. size and density) as a function of forest type (e.g. Very dense forest, moderate and open forests) and regeneration stage. The variability of AGB is a function of incidence angle. After quantifying both the polarization for biomass estimation the combined polarization of C-band and L-band has been tried by various workers for biomass estimation and mapping in various forest types (Dobson et al. 1995, Harrell et al. 1997). The L-band wavelength founds to be more effective in estimating the stem volume as compared to $\mathrm{C}$-band images. The region of forest areas having less forest biomass can be evaluated with $\mathrm{X}$ band, but L-band is required for higher biomass range. The combined used of both the bands (X \& L) produced the most accurate result for AGB estimation (Englhart et al. 2011).

After polarimetric technique, another technique known as interferometry technique has also been evaluated for the estimation of forest biomass. In interferometry, a relation has been tried to establish between X-band Interferometric height above ground and AGB (Solberg et al. 2017). Although the technique has not obtained a greater accuracy and the RMSE was too high (203 t/ha). The reason being given that it may be due to less number of sample plot and a less sensitivity of InSAR height with basal area and stem density. The TerraSAR-X PolInSAR data were analyzed to study the consequence of seasons on the estimation of forest parameters in deciduous forests in India. It has been reported that PolInSAR based height inversion performance depends upon the phonological change in the forest. Those species which were not under phonological change (leaf on) gives height inversion accuracy $\left(\mathrm{R}^{2}=0.75\right)$ than those which are going under successional change $\left(\mathrm{R}^{2}=0.65\right)$. The TanDEM-X data was used for the modeling of biomass in tropical peat swamp forest using in-situ field inventory data and LiDAR based canopy height model (Schlund et al. 2014). A medium to high coefficient of correlation $\left(\mathrm{R}^{2}=0.5\right)$ has been obtained between interferometric coherence with the biomass. The results specify the potential of interferometric coherence for the estimation of AGB in tropical peat swamp forest.

The P-Band SAR sensors are also capable for the quantification of forest above ground biomass. The world is launching "the BIOMASS mission" (P-band) satellite in which 2020 for mapping of global forest above ground biomass map (ESA 2012). The upcoming developed map will help in making world's forest cover map, making national inventory plan and calculation of global carbon flux. It will publish biannual biomass maps for all rainforests and part of the boreal and temperate forests with a maximum allowable uncertainty of $20 \%$ (ESA2012). Another technique which is gaining the pace in the current scenario is the use of TomoSAR which has the capabilities to calculate canopy height with an error 
within $2.5 \mathrm{~m}$ taking high-resolution LiDAR canopy model as a reference. The result emphasized the potential of TomoSAR-AGB retrieval method in rigorous terrain and high-biomass forest areas with greater accuracy with a conclusion to generalize the method for other forest areas having a canopy height greater than $30 \mathrm{~m}$ (Minh et al. 2016).

\section{Methodologies Adopted for AGB Estimation using SAR Data}

Various methodologies have been adopted since past for the retrieval of forest parameters for biomass modeling including empirical (Harrell et al. 1997, Lucas et al. 2000, Ranson et al.1995, Sandberg et al. 2011), subsequently, semi-empirical (Lu 2006, Pulliainen et al. 1996, Kurvonen et al. 1999, Santoro et al. 2006) and, more recently numerical (Burgin et al. 2011, Lucas et al. 2004) models. In empirical models, the radar backscatter has been related with in-situ biomass using regression analysis taking various functional forms into account, including linear (Sandberg et al. 2011), logarithmic (Moreau \& Le Toan, 2003), exponential (Englhart et al. 2011, Moreau \& Le Toan, 2003) and higher degree polynomials (Dobson et al. 1992). The regression analysis has been performed between the backscatter coefficient and the plot level biomass. The regression coefficient has been used for the determination of best suited model. A significant correlation coefficients were obtained between backscatter intensity and biophysical parameters. The significance level may increase using multi-variate regression analysis (Rauste 2005, Mitchard et al. 2009, Sarkar and Nichol 2011). The combination of JERS SAR with optical regression analysis will further improve the correlation coefficient and reduces the saturation level. The various approaches revealed that SAR backscatter correlate negatively with forest biomass after reaching a certain value (Mermoz et al. 2014).Generalized Linear Model (GLM) and Generalized Boosted Model (GBM) have been used along with terrain and canopy structure factors for the estimation of AGB in Northeastern China (Ma et al. 2017). It has been reported that GBM model is significant for coniferous forests ( $\mathrm{RMSE}=3.81 \mathrm{Mg} \mathrm{ha}^{-1}, \mathrm{R}^{2}=0.98$ ), mixed forest $\left(\mathrm{RMSE}=17.72 \mathrm{Mg} \mathrm{ha}^{-1}, \mathrm{R}^{2}=0.96\right)$ and broadleaf forest $\left(\mathrm{RMSE}=19.94 \mathrm{Mg} \mathrm{ha}^{-1}, \mathrm{R}^{2}=0.96\right)$ than GLM model for establishing the relationships between AGB and PALSAR backscatter coefficients. It has further been improvised by taking topography and canopy structure factors into variable in regression. The biomass modeling through regression has been done using TerraSAR-X \& ALOS PALSAR, separately and in combination which concludes the significance of multi-temporal regression model over single band based models due to significant coefficient of correlation and lower RMSE. TheWater Cloud Model (WCM) is a semi-empirical models developed by Attema \& Ulaby in 1978 which has been used to derive the response of vegetation from radar backscatter. It is based on the principal that the tree canopy acts as a cloud of water droplets in which water droplets are randomly distributed (Attema and Ulaby, 1978). The effect of vegetation water content on the radar backscattering coefficients was taken into account by using Water Cloud Model (WCM). The same model has been tested over Sweden, Finland and Siberiausing JERS-1 L-band SAR backscatter for estimation of stem volume (Santoro et al. 2006). A difference of $\sim 4 \mathrm{~dB}$ has been observed in the backscatter coefficient from the dense forests whereas in medium dense forest and open forests, its backscatter depends on the dielectric properties of the forest floor (Santoro et al. 2006, Englhart et al. 2012). The parameters of the Water Cloud Model were retrieved using Generic Algorithm (GA) and Sequential Unconstrained Minimization Technique (SUMT) in India (Kumar et al. 2012). It was found that GA technique performed better than SUMT in parameter estimation, where the Root Mean Square Error (RMSE) was about half of that obtained by SUMT. Another technique known as Machine learning algorithms has also been used for deriving forest tress parameters from polarimetric SAR data (Neumann et al. 2012). After many techniques being used and implemented for different forest types the best model is yet to derive (Harrell et al. 1995, Harrell et al. 1997, Neumann et al. 2012, Robinson et al. 2013, Saatchi et al. 2007, Saatchi et al. 2011, Sandberg et al. 2011). A semi-empirical model and machine-learning algorithm were compared with bagging stochastic gradient boosting 
(BragSGB) equation for the assessment of above forest biomass in Guinea-Bissau, taking L-band ALOS PALSAR data. A very significant coefficient of correlation $\left(\mathrm{R}^{2}=0.95\right)$ and a root mean square error (RMSE) of $26.62 \mathrm{Mg}$ ha-1 has been observed between modeled biomass and predicted biomass(Carreiras et al. 2014). Englhart et al. 2012 analyzed the Multivariate linear regression (MLR), Artificial Neural Network (ANN), Support Vector Machine (SVM) for the estimation of ABG in Indonesia's peatswamp forests using time series data of TerraSAR-X and ALOS-PALSAR. MLR model results lowest $\mathrm{R}^{2}$ and highest errors. SVR model concluded that it was a superior method because of its highest $\mathrm{R}^{2}$ and lowest errors. But, it shows a saturation effects, and thus the entire range of biomass could not be mapped accurately. The ANN method was the most appropriate among all (MLR, SVM) because it was not influenced by the high biomass region (647 t/ha). The only limitation being faced is only due to lack of mathematical relationship between backscatter signals and biomass (Wijaya et al. 2010, Xie et al. 2009, Foddy et al. 2003, Muukkonen et al. 2005).

Bhardwaj et al. 2015 used the Polarimetric decomposition technique and Extended Water Cloud Model (EWCM) for the estimation of AGB in Dudhwa national Park in India. The scattering components from decomposition and parameter retrieval for EWCM acquired from quad polarized ALOS PALSAR data. The coefficient of correlation $\left(\mathrm{R}^{2}\right)$ and RMSE were 0.4341 and 119t/ha respectively. Vaiga et al. 2016 used Maximum Entropy (MaxEnt) algorithm to modelforest biomass, the uncertainty in its mapping and probability maps of forest in Mexico. The inputs for the model have derived from the MODIS vegetation index, ALOS PLASAR dual polarization backscatter images and SRTM digital elevation model. The ALOS PALSAR layer has highest contribution (50.9\%) in forest AGB mapping followed by MODIS (32.9) and SRTM DEM (16.2\%). The validation of AGB map with inventory plots showed a RMSE error 17.3 t C/ha and $\mathrm{R}^{2}=0.31$. The maximum entropy model developed using in-situ forest data has provided a sub-pixel level accurate map of forest biomass which plays a pivotal role in REDD+ applications. It can further be enhanced using large number of sample plots as input to the model for mapping at regional and national scale. ENVISAT ASAR C-band backscatter, InSAR coherence and semi-emperical model were used for the estimation of AGB over a tropical forest area in India. The higher accuracy $\left(\mathrm{R}^{2}=0.73, \mathrm{RMSE}=53.76 \mathrm{Mg} / \mathrm{ha}\right)$ has been acquired using temporal data with water cloud model. The temporal data of InSAR coherence produce significant $\left(\mathrm{R}^{2}=0.90, \mathrm{RMSE}=35.92 \mathrm{t} / \mathrm{ha}\right)$ results compared to single InSAR coherence image. The potential of InSAR coherence has well proven over SAR backscatter due to greater accuracy and higher saturation limit for forest biomass (Kumar et al. 2015). The capabilities of ALOS PLASAR backscatter and InSAR coherence were investigated for the estimation of forest Growing Stock Volume (GSV) in Central Siberia, Russia (Thiel and Schmullius 2015). In the current scenario, all the available data sets available has been tried and implemented over different forest type for better estimation of forest above ground biomass.

\section{DISCUSSIONS}

The spaceborne SAR seems to be very useful for measuring biomass and forest carbon tracking over a larger area. The research paper reviewed above demonstrated the existence of relationship between forests AGB with different frequencies of Synthetic Aperture Radar data. The longer wavelength and shorter frequency featuring SAR data is capable to penetrate deep inside the forest and its weak backscatter coefficient from rough surface makes it crucial for the assessment of forest biomass. A significant coefficient of correlation has been obtained between SAR backscatter and forest AGB in P-band and insignificant in C-band (Dobson et al. 1992, Israelsson et al. 1992, Rauste et al. 1992). Not only radar backscatterare correlated but also the interferometric coherence are also sensitive to canopystructure and forest above ground biomass (Schlund et al. 2014). It also depends upon the forest height. Therefore, to obtain a significant relationship between radar 
backscatter and ground data, it is suggestive to use large plot size and number of plots which should be stratified randomly distributed in case of very dense forest which are rich in biodiversity. The interferometric coherence is being influenced by tree canopy density and its height. The coherence decreases with increasing biomass due to higher volume decorrelation caused by larger vertical height and more closed canopy.

The review have reported that the saturation of SAR data depends on the frequency, polarization forest characteristics and some other factor like weather, soil moisture and surfarce roughness.

The C-band saturates at approximately 30-50 t/ha, whereas for L-band and P-band saturates at 100-150 t/ha and $>150 \mathrm{t} / \mathrm{ha}$ respectively. The saturation limit dependents upon vegetation structure, soil moisture conditions and forest management practices. The saturation limit can be overcome largely using different techniques such as polarization ratios, time series SAR data, combination of optical and SAR data, inversion method, texture based method and InSAR-Lidar method for the retrieval of parameters. The slope correction algorithm improves the quality of the SAR data, which further improves the texture quality and the above forest carbon stock estimation. The review suggests that, the applicability of the AGB assessment depends upon pre-processing of SAR data. There is a need to apply geometric correction using Digital Elevation Model (DEM), radiometric calibration, de-orientation and local incidence correction, before parameter extraction. The majority of the studies were restricted to relatively flat terrain due to the difficulties of SAR distortions such as layover, foreshortening and shadow effect caused by the hilly terrain. Therefore, it is suggestive to inculcate terrain information as input for mapping and modeling of accurate forest above ground biomass.

\section{REFERENCES}

1. Abed, Rasheed Saleem, and Gassan Najim Abdullah. "Geometry and Leaning of Alhadba Minaret." International Journal of Civil, Structural, Environmental and Infrastructure Engineering Research and Development (IJCSEIERD) 8.1 (2018): 1-8.

2. Attema, E. P. W., \& Ulaby, F. T. (1978). Vegetation modeled as a water cloud. Radio Science, 13(2), p. 357-364.

3. Atwood, D. K., Andersen, H.-E., Matthiss, B., \& Holecz, F. (2014). Impact of topographic correction on estimation of aboveground boreal biomass using multi-temporal, L-band backscatter. IEEE Journal of Selected Topics in Applied Earth Observations and Remote Sensing, 7(8), p. 3262-3273.

4. Baker, J. R., Mitchell, P. L., Cordey, R. A., Groom, G. B., Settle, J. J., \& Stileman, M. R. (1994). Relationships between physical characteristics and polarimetric radar backscatter for Corsican pine stands in Thetford Forest, UK. International Journal of Remote Sensing, 15(14), p. 2827-2849.

5. Bastin, G., Denham, R., Scarth, P., Sparrow, A., and Chewings, V., Schmidt (2014). Remotely Sensed Analysis of Vegetation Cover Change across Queensland's Rangelands 1988-2005. The Rangeland Journal 36, p. 191-204.

6. Behera, M. D., Tripathi, P., Mishra, B., Kumar, S., Chitale, V. S., and Behera, S. K. (2016). Above-ground biomass and carbon estimates of Shorea robusta and Tectona grandis forests using QuadPOL ALOS PALSAR data. Advances in Space Research, 57(2), p.552-561.

7. Bharadwaj, P. S., Kumar, S., Kushwaha, S. P. S., \& Bijker, W. (2015). Polarimetric scattering model for estimation of above ground biomass of multilayer vegetation using ALOS-PALSAR quad-pol data. Physics and Chemistry of the Earth, Parts $A / B / C, 83, p .187-195$.

8. Bijalwan, A., Swamy, S. L., Sharma, C. M., Sharma, N. K., \& Tiwari, A. K. (2010). Land-use, biomass and carbon estimation in dry tropical forest of Chhattisgarh region in India using satellite remote sensing and GIS. Journal of Forestry Research, 21(2), p.161-170. 
9. Burgin, M., Clewley, D., Lucas, R. M., and Moghaddam, M. (2011). A generalized radar backscattering model based on wave theory for multilayer multispecies vegetation. IEEE Transactions on Geoscience and Remote Sensing, 49(12), p.4832-4845.

10. Carreiras, J. M. B., Vasconcelos, M. J., and Lucas, R. M. (2012). Understanding the relationship between aboveground biomass and ALOS PALSAR data in the forests of Guinea-Bissau (West Africa). Remote Sensing of Environment, 12(1), p. 426-442.

11. Cartus, O., Santoro, M., and Kellndorfer, J. (2012a). Mapping forest aboveground biomass in the Northeastern United States with ALOS PALSAR dual-polarization L-band. Remote Sensing of Environment, 12(4), p. 466-478.

12. Chhabra, A., Palria, S. and Dadhwal, V.K. (2002). Growing stock-based forest biomass estimate for India. Biomass and bioenergy, 22(3), p.187-194.

13. Chhabra, A., Palria, S., and Dadhwal, V. K. (2002). Spatial distribution of phytomass carbon in Indian forests. Global Change Biology, 8(12), p.1230-1239.

14. Chiesi, M., Maselli, F., Bindi, M., Fibbi, L., Cherubini, P., Arlotta, E., Tirone, G., Matteucci, G. and Seufert, G. (2005). Modelling carbon budget of Mediterranean forests using ground and remote sensing measurements. Agricultural and Forest Meteorology, 135(1-4), p.22-34.

15. Dadhwal, V. K. (1997). Recent changes [1982-1991] in forest phytomass carbon pool in India estimated using growing stock and remote sensing-based forest inventories. Journal of Tropical Forestry, 13, p. 182-188.

16. Dobson, M. C., Ulaby, F. T., LeToan, T., Beaudoin, A., Kasischke, E. S., and Christensen, N. (1992). Dependence of radar backscatter on coniferous forest biomass. IEEE Transactions on Geoscience and Remote Sensing, 30(2), p. 412-415.

17. Dobson, M. C., Ulaby, F. T., Pierce, L. E., Sharik, T. L., Bergen, K. M., Kellndorfer, J. (1995). Estimation of forest biophysical characteristics in Northern Michigan with SIR-C/X-SAR. IEEE Transactions on Geoscience and Remote Sensing, 33(4), p. $877-895$.

18. Englhart, S., Keuck, V. and Siegert, F. (2011). Aboveground biomass retrieval in tropical forests-The potential of combined $X$-and L-band SAR data use. Remote sensing of environment, 115(5), p.1260-1271.

19. FAO (2005). State of the World's Forests. FAO, Rome.

20. Foody, G., Boyd, D. and Cutler, M. (2003). Predictive relations of tropical forest biomass from LANDSAT TM data and their transferability between regions. Remote Sensing of Environment, 85, p. 463-474.

21. FSI (2017). India State of Forest Report, (2017). Forest Survey of India, Ministry of Environment and Forests Government of India, Dehra Dun, India.

22. Gaikwad, Nikita, Yogita Mistry, and Kiran Inamdar. "Design and Implementation of Energy Efficient Environment Monitoring System." International Journal of Electronics, Communication \& Instrumentation Engineering Research and Development (IJECIERD) ISSN (P) (2016).

23. Gibbs, H. K., Brown, S., Niles, J.O. and Foley, J.A. (2007). Monitoring and estimating tropical forest carbon stocks: making REDD a reality. Environmental Research Letter, 2(4), p. 045023.

24. Goward, S. N., and Dye, D. G. (1987). Evaluation of North American net primary productivity with satellite data: Advances in Space Research, 7 (11), p. 165-174.

25. Hamdan, O., Aziz, H. K., \& Hasmadi, I. M. (2014). L-band ALOS PALSAR for biomass estimation of Matang Mangroves, Malaysia. Remote Sensing of Environment, 155, p. 69-78. 
26. Harrell, P. A., Bourgeau-Chavez, L. L., Kasischke, E. S., French, N. H. F., and Christensen, N. L. (1995). Sensitivity of ERS-1 and JERS-1 radar data to biomass and stand structure in Alaskan boreal forest. Remote Sensing of Environment, 54(3), p. 247-260.

27. Harrell, P. A., Bourgeau-Chavez, L. L., Kasischke, E. S., French, N. H. F., and Christensen, N. L. (1995). Sensitivity of ERS-1 and JERS-1 radar data to biomass and stand structure in Alaskan boreal forest. Remote Sensing of Environment, 54(3), p. $247-260$.

28. Harrell, P. A., Kasischke, E. S., Bourgeau Chavez, L. L., Haney, E. M., \& Christensen Jr., N. L. (1997). Evaluation of approaches to estimating aboveground biomass in Southern pine forests using SIR-C data. Remote Sensing of Environment, 59(96), p. 223-233.

29. Harrell, P. A., Kasischke, E. S., Bourgeau Chavez, L. L., Haney, E. M., \& Christensen Jr., N. L. (1997). Evaluation of approaches to estimating aboveground biomass in Southern pine forests using SIR-C data. Remote Sensing of Environment, 59(96), p. 223-233.

30. Hoekman, D. H., and Quiriones, M. J. (2000). Land cover type and biomass classification using AirSAR data for evaluation of monitoring scenarios in the Colombian Amazon. IEEE Transactions on Geoscience and Remote Sensing, 38(2), p. 685-696.

31. Huete, A., Didan, K., Miura, T., Rodriguez, E.P., Gao, X. and Ferreira, L.G. (2002). Overview of the radiometric and biophysical performance of the MODIS vegetation indices. Remote sensing of environment, 83(1-2), p.195-213.

32. II.Sc (2006). Forest conservation and afforestation/reforestation in India: implications of forest carbon stocks and sustainable development. Report of project No.6/2/2006-CCC. Indian Institute of Science, Bangalore, 560 012, India.

33. Imhoff, M. L. (1995). IV. CONCLUSIONS. IEEE Transactions on Geoscience and Remote Sensing, 33(2), p. 511.

34. Israelsson, H., Askne, J., and Sylvander, R. (1994). Potential of SAR for forest bole volume estimation. International Journal of Remote Sensing, 15(14), p. 2809-2826.

35. Kale, M. P., Ravan, S. A., Roy, P. S., and Singh, S. (2009). Patterns of carbon sequestration in forests of Western Ghats and study of applicability of remote sensing in generating carbon credits through afforestation/reforestation. Journal of the Indian Society of Remote Sensing, 37(3), p. 457-471.

36. Kale, M., Singh, S., Roy, P. S., Deosthali, V., and Ghole, V. S. (2004). Biomass equations of dominant species of dry deciduous forest in Shivpuri district, Madhya Pradesh. Current Science, p. 683-687.

37. Kasischke, E. S., Christensen, N. L., and Bourgeau-Chavez, L. L. (1995). Correlating radar backscatter with components of biomass in loblolly pine forests. IEEE Transactions on Geoscience and Remote Sensing, 33(3), p. 643-659.

38. Kasischke, E. S., French, N. H. F., and Bourgeau-Chavez, L. L. (1997). Monitoring of the effects of fire in North American boreal forests using ERS SAR imagery.

39. Kumar, R., Gupta, S. R., Singh, S., Patil, P., and Dhadhwal, V. K. (2011). Spatial distribution of forest biomass using remote sensing and regression models in northern Haryana, India. International Journal of Ecology and Environmental Sciences, 37(1), p. 37-47.

40. Kumar, S., Pandey, U., Kushwaha, S. P., Chatterjee, R. S., and Bijker, W. (2012). Aboveground biomass estimation of tropical forest from Envisat advanced synthetic aperture radar data using modeling approach. Journal of Applied Remote Sensing, 6(1), p. 63588.

41. Kurvonen, L., Pulliainen, J., and Hallikainen, M. (1999). Retrieval of biomass in boreal forests from multitempotal ERS-1 and JERS-1 SAR images. IEEE Transactions on Geoscience and Remote Sensing, 37(1), p. 198-205. 
42. Lal, M., and Singh, R. (2000). Carbon sequestration potential of Indian forests. Environmental Monitoring and Assessment, 60(3), p. 315-327.

43. Le Toan, T., Beaudoin, A., Riom, J., and Guyon, D. (1992). Relating forest biomass to SAR data. IEEE Transactions on Geoscience and Remote Sensing, 30(2), p. 403-411.

44. Lizuka, K. and Tateishi, R. (2014). Simple relationship analysis between L-band backscattering intensity and the stand characteristics of sugi (Cryptomeria japonica) and hinoki (Chamaecyparisobtusa) trees. Advances in Remote Sensing, 3(04), p.219.

45. Lu, D. (2006). The potential and challenge of remote sensing-based biomass estimation. International Journal of Remote Sensing, 27(7), p. 1297-1328.

46. Lu, D., Chen, Q., Wang, G., Liu, L., Li, G. and Moran, E. (2016). A survey of remote sensing-based aboveground biomass estimation methods in forest ecosystems. International Journal of Digital Earth, 9(1), p.63-105.

47. Lu, D., Chen, Q., Wang, G., Liu, L., Li, G. and Moran, E. (2016). A survey of remote sensing-based aboveground biomass estimation methods in forest ecosystems. International Journal of Digital Earth, 9(1), p.63-105.

48. Lucas, R. M., Milne, A. K., Cronin, N., Witte, C., and Denham, R. (2000). The potential of synthetic aperture radar (SAR) for quantifying the biomass of Australia's woodlands. The Rangeland Journal, 22(1), p. 124-140.

49. Lucas, R. M., Moghaddam, M., and Cronin, N. (2004). Microwave scattering from mixed-species forests, Queensland, Australia. IEEE Transactions on Geoscience and Remote Sensing, 42(10), p. 2142-2159.

50. Lucas, R., Armston, J., Fairfax, R., Fensham, R., Accad, A. and Carreiras, J. (2010). An evaluation of the ALOS PALSAR Lband backscatter-Above ground biomass relationship Queensland, Australia: Impacts of surface moisture condition and vegetation structure. IEEE Journal of Selected Topics in Applied Earth Observations and Remote Sensing, 3(4), p. 576-593.

51. Lucas, R., Armston, J., Fairfax, R., Fensham, R., Accad, A. and Carreiras, J. (2010). An evaluation of the ALOS PALSAR Lband backscatter-Above ground biomass relationship Queensland, Australia: Impacts of surface moisture condition and vegetation structure. IEEE Journal of Selected Topics in Applied Earth Observations and Remote Sensing, 3(4), p. 576-593.

52. Luckman, A., Baker, J., and Wegmüller, U. (2000). Repeat-pass interferometric coherence measurements of disturbed tropical forest from JERS and ERS satellites. Remote Sensing of Environment, 73(3), p. 350-360.

53. Luckman, A., Baker, J., Honzák, M., and Lucas, R. (1998). Tropical forest biomass density estimation using JERS-1 SAR: Seasonal variation, confidence limits, and application to image mosaics. Remote Sensing of Environment, 63(2), p. 126-139.

54. Luckman, A., Baker, J., Kuplich, T. M., Corina da Costa, F. Y., and Alejandro, C. F. (1997). A study of the relationship between radar backscatter and regenerating tropical forest biomass for spaceborne SAR instruments. Remote Sensing of Environment, 60(1), p. 1-13.

55. Ma, J., Xiao, X., Qin, Y., Chen, B., Hu, Y., Li, X., and Zhao, B. (2017). Estimating aboveground biomass of broadleaf, needleleaf, and mixed forests in Northeastern China through analysis of 25-m ALOS/PALSAR mosaic data. Forest Ecology and Management, 389, p. 199-210.

56. Madugundu, R., Nizalapur, V., and Jha, C. S. (2008). Estimation of LAI and above-ground biomass in deciduous forests: Western Ghats of Karnataka, India. International Journal of Applied Earth Observation and Geoinformation, 10(2), p. 211219.

57. Mani, S., and Parthasarathy, N. (2007). Above-ground biomass estimation in ten tropical dry evergreen forest sites of peninsular India. Biomass and Bioenergy, 31(5), p. 284-290. 
58. Mermoz, S., Le Toan, T., Villard, L., Réjou-Méchain, M., and Seifert-Granzin, J. (2014). Biomass assessment in the Cameroon savanna using ALOS PALSAR data. Remote Sensing of Environment, 155, p. 109-119.

59. Minh, D. H. T., Le Toan, T., Rocca, F., Tebaldini, S., d'Alessandro, M. M., and Villard, L. (2014). Relating P-band synthetic aperture radar tomography to tropical forest biomass. IEEE Transactions on Geoscience and Remote Sensing, 52(2), p. 967979.

60. Mitchard, E. T. A., Feldpausch, T. R., Brienen, R. J. W., Lopez-Gonzalez, G., Monteagudo, A., and Baker, T. R. (2014). Markedly divergent estimates of A mazon forest carbon density from ground plots and satellites. Global Ecology and Biogeography, 23(8), p. 935-946.

61. Mitchard, E. T. A., Saatchi, S. S., Woodhouse, I. H., Nangendo, G., Ribeiro, N. S., Williams, M., and Meir, P. (2009). Using satellite radar backscatter to predict above-ground woody biomass: A consistent relationship across four different African landscapes. Geophysical Research Letters, 36(23).

62. Moreau, S., and Le Toan, T. (2003). Biomass quantification of Andean wetland forages using ERS satellite SAR data for optimizing livestock management. Remote Sensing of Environment, 84(4), p. 477-492.

63. Morel, A. C., Saatchi, S. S., Malhi, Y., Berry, N. J., Banin, L., Burslem, D. and Ong, R. C. (2011). Estimating aboveground biomass in forest and oil palm plantation in Sabah, Malaysian Borneo using ALOS PALSAR data. Forest Ecology and Management, 262(9), p. 1786-1798.

64. Muukkonen, P. and Heiskanen, J. (2007). Biomass estimation over a large area based on standwise forest inventory data and ASTER and MODIS satellite data: A possibility to verify carbon inventories. Remote Sensing of Environment, 107(4), p.617624.

65. Myeong, S., Nowak, D.J. and Duggin, M.J. (2006). A temporal analysis of urban forest carbon storage using remote sensing. Remote Sensing of Environment, 101(2), p.277-282.

66. Nakaji, T., Ide, R., Takagi, K., Kosugi, Y., Ohkubo, S., Nasahara, K.N., Saigusa, N. and Oguma, H. (2008). Utility of spectral vegetation indices for estimation of light conversion efficiency in coniferous forests in Japan. Agricultural and forest meteorology, 148(5), p.776-787.

67. Neumann, M., Saatchi, S. S., Ulander, L. M. H., and Fransson, J. E. S. (2012). Assessing performance of L-and P-band polarimetric interferometric SAR data in estimating boreal forest above-ground biomass. IEEE Transactions on Geoscience and Remote Sensing, 50(3), p. 714-726.

68. Nichol, J.E and Sarker, M.L.R. (2011). Improved biomass estimation using the texture parameters of two high-resolution optical sensors. IEEE Transaction on Geosciences and Remote Sensing, 49(3), p. 930-948.

69. Padalia, H., and Yadav, S. (2017). Evaluation of RISAT-1 SAR data for tropical forestry applications. Advances in Space Research, 59(1), p. 2-11.

70. Pandey, U., Kushwaha, S. P. S., Kachhwaha, T. S., Kunwar, P., \& Dadhwal, V. K. (2010). Potential of Envisat ASAR data for woody biomass assessment. Tropical Ecology, 51(1), p. 117.

71. Patil, Bhagyashree, and Maruti Limkar. "Machine to Machine Communication Based Electricity Monitoring and Billing System." International Journal of Electrical and Electronics Engineering Research (IJEEER) ISSN (P) (2016).

72. Ploton, P., Pélissier, R., Proisy, C., Flavenot, T., Barbier, N., Rai, S. N., and Couteron, P. (2012). Assessing aboveground tropical forest biomass using Google Earth canopy images. Ecological Applications, 22(3), p. 993-1003. 
73. Pulliainen, J. T., Heiska, K., Hyyppa, J., and Hallikainen, M. T. (1994). Backscattering properties of boreal forests at the Cand X-bands. IEEE Transactions on Geoscience and Remote Sensing, 32(5), p. 1041-1050.

74. Pulliainen, J. T., Kurvonen, L., and Hallikainen, M. T. (1999). Multitemporal behavior of L-and C-band SAR observations of boreal forests. IEEE Transactions on Geoscience and Remote Sensing, 37(2), p. 927-937.

75. Pulliainen, J. T., Mikhela, P. J., Hallikainen, M. T., and Ikonen, J.-P. (1996). Seasonal dynamics of C-band backscatter of boreal forests with applications to biomass and soil moisture estimation. IEEE Transactions on Geoscience and Remote Sensing, 34(3), p. 758-770.

76. Pulliainen, J., Kurvonen, L. and Hallikainen, M., (1997). Effect of temporally varying parameters on L-and C-band SAR observations of boreal forests. In IGARSS'97. 1997 IEEE International Geoscience and Remote Sensing Symposium Proceedings. Remote Sensing-A Scientific Vision for Sustainable Development (Vol. 4, pp. 1874-1877). IEEE.

77. Ramachandran, A., Jayakumar, S., Haroon, R. M., Bhaskaran, A., and Arockiasamy, D. I. (2007). Carbon sequestration: estimation of carbon stock in natural forests using geospatial technology in the Eastern Ghats of Tamil Nadu, India. Current Science, p. 323-331.

78. Ranson, K. J., Saatchi, S., and Sun, G. (1995). Boreal forest ecosystem characterization with SIR-C/XSAR. IEEE Transactions on Geoscience and Remote Sensing, 33(4), p. 867-876.

79. Rauste, Y. (1990). Incidence-angle dependence in forested and non-forested areas in Seasat SAR data. International Journal of Remote Sensing, 11(7), p. 1267-1276.

80. Rauste, Y. (2005). Multi-temporal JERS SAR data in boreal forest biomass mapping. Remote Sensing of Environment, 97(2), p. $263-275$.

81. Ravindranath, N. H., Somashekhar, B. S., and Gadgil, M. (1997). Carbon flow in Indian forests. Climatic Change, 35(3), p. 297-320.

82. Ravindranath, N.H., Kumar, R., Chaturvedi and Murthy, I.K. (2008). Forest conservation, afforestation and reforestation in India: Implications for forest carbon stocks. Current Science : 21695 (2): p. 216-222.

83. Robinson, C., Saatchi, S., Neumann, M., and Gillespie, T. (2013). Impacts of spatial variability on aboveground biomass estimation from L-band radar in a temperate forest. Remote Sensing, 5(3), p. 1001-1023.

84. Saatchi, S. S., Harris, N. L., Brown, S., Lefsky, M., Mitchard, E. T. A. and Salas, W. (2011). Benchmark map of forest carbon stocks in tropical regions across three continents. Proceedings of the National Academy of Sciences, 108(24), p. 9899-9904.

85. Saatchi, S., Halligan, K., Despain, D. G., and Crabtree, R. L. (2007). Estimation of forest fuel load from radar remote sensing. IEEE Transactions on Geoscience and Remote Sensing, 45(6), p. 1726-1740.

86. Saatchi, S., Halligan, K., Despain, D. G., and Crabtree, R. L. (2007). Estimation of forest fuel load from radar remote sensing. IEEE Transactions on Geoscience and Remote Sensing, 45(6), p. 1726-1740.

87. Sandberg, G., Ulander, L. M. H., Fransson, J. E. S., Holmgren, J., and Le Toan, T. (2011). L-and P-band backscatter intensity for biomass retrieval in hemiboreal forest. Remote Sensing of Environment, 115(11), p. 2874-2886.

88. Sandberg, G., Ulander, L. M. H., Fransson, J. E. S., Holmgren, J., and Le Toan, T. (2011). L-and P-band backscatter intensity for biomass retrieval in hemiboreal forest. Remote Sensing of Environment, 115(11), p. 2874-2886.

89. Santoro, M., Eriksson, L., Askne, J., and Schmullius, C. (2006). Assessment of stand-wise stem volume retrieval in boreal forest from JERS-1 L-band SAR backscatter. International Journal of Remote Sensing, 27(16), p. 3425-3454. 
90. Santoro, M., Fransson, J. E. S., Eriksson, L. E. B., Magnusson, M., Ulander, L. M. H., and Olsson, H. (2009). Signatures of ALOS PALSAR L-band backscatter in Swedish forest. IEEE Transactions on Geoscience and Remote Sensing, 47(12), p. $4001-4019$.

91. Sarker, M. L. R., Nichol, J., Iz, H. B., Ahmad, B. Bin, and Rahman, A. A. (2013). Forest biomass estimation using texture measurements of high-resolution dual-polarization C-band SAR data. IEEE Transactions on Geoscience and Remote Sensing, 51(6), p. 3371-3384.

92. Schlund, M., von Poncet, F., Hoekman, D. H., Kuntz, S., and Schmullius, C. (2014). Importance of bistatic SAR features from TanDEM-X for forest mapping and monitoring. Remote Sensing of Environment, 151, p. 16-26.

93. Schlund, M., von Poncet, F., Hoekman, D. H., Kuntz, S., and Schmullius, C. (2014). Importance of bistatic SAR features from TanDEM-X for forest mapping and monitoring. Remote Sensing of Environment, 151, p. 16-26.

94. Sharma, D. P., and Singh, M. (2010). Assessing the carbon sequestration potential of subtropical pine forest in north-western Himalayas-a GIS approach. Journal of the Indian Society of Remote Sensing, 38(2), p. 247-253.

95. Sheikh, M. A., Kumar, M., Bussman, R. W., and Todaria, N. P. (2011). Forest carbon stocks and fluxes in physiographic zones of India. Carbon Balance and Management, 6(1), p. 15.

96. Singh, V., Tewari, A., Kushwaha, S. P. S., and Dadhwal, V. K. (2011). Formulating allometric equations for estimating biomass and carbon stock in small diameter trees. Forest Ecology and Management, 261(11), p. 1945-1949.

97. Solberg, S., Hansen, E. H., Gobakken, T., Naessset, E., and Zahabu, E. (2017). Biomass and InSAR height relationship in a dense tropical forest. Remote Sensing of Environment, 192, p. 166-175.

98. Tan, K., Piao, S., Peng, C., Fang, J. (2007). Satellite based estimation of biomass carbon stocks for northeast China's forests between 1982 and 1999. Forest Ecology and Environment, 240(1-3), pp. 114-121.

99. Thakur, T., and Swamy, S. L. (2012). Analysis of land use, diversity, biomass, $C$ and nutrient storage of a dry tropical forest ecosystem of India using satellite remote sensing and GIS techniques. In Proceedings of International Forestry and Environment Symposium (Vol. 15).

100. Thiel, C., and Schmullius, C. (2016). The potential of ALOS PALSAR backscatter and InSAR coherence for forest growing stock volume estimation in Central Siberia. Remote Sensing of Environment, 173, p. 258-273.

101. Tucker, C. J., Vanpraet, C., Boerwinkle, E. and Gaston, A. (1983). Satellite remote sensing of total dry matter accumulation in the Senegalese Sahel. Remote Sensing of Environment. 13 p. 461-474.

102. UNFCCC (2011). Report of the Global Environment Facility to the conference of Parties.

103. van Zyl, J. J., Chapman, B. D., Dubois, P., and Shi, J. (1993). The effect of topography on SAR calibration. IEEE Transactions on Geoscience and Remote Sensing, 31(5), 1036-1043.

104. Wang, G., Oyana, T., Zhang, M., Adu-Prah, S., Zeng, S., Lin, H. and Se, J. (2009). Mapping and spatial uncertainty analysis of forest vegetation carbon by combining national forest inventory data and satellite images. Forest Ecology and Management, 258(7), p.1275-1283.

105. Wang, Y., Davis, F. W., and Melack, J. M. (1995). The effects of changes in forest biomass on radar backscatter from tree canopies. Remote Sensing, 16(3), p. 503-513.

106. Whittle, M., Quegan, S., Uryu, Y., Stüewe, M., and Yulianto, K. (2012). Detection of tropical deforestation using ALOSPALSAR: A Sumatran case study. Remote Sensing of Environment, 124, p. 83-98. 
107. Wijaya, A., Kusnadi, S., Gloaguen, R. and Heilmeier, H. (2010). Improved strategy for estimating stem volume and forest biomass using moderate resolution remote sensing data and GIS. Journal of Forestry Research, 21(1), p.1-12.

108. Xie, Y., Sha, Z., Yu, M., Bai, Y. and Zhang, L. (2009). A comparison of two models with Landsat data for estimating above ground grassland biomass in Inner Mongolia, China. Ecological Modelling, 220(15), p.1810-1818.

109. Zabbar, Md Ajijul Bin, and Chisty Nafiz Ahmed. "Design \& Implementation of an Unmanned Ground Vehicle (UGV) Surveillance Robot." International Journal of Electrical and Electronics Engineering (IJEEE) 5.6 (2016): 2278-9944. 

